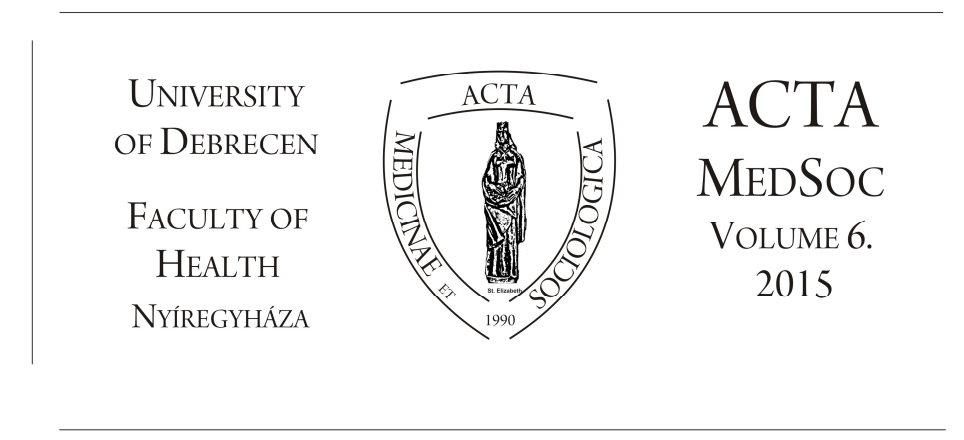

\title{
Active Participation of Parents as an Integral Part a Social Rehabilitation Process
}

\author{
${ }^{1}$ Martin Karas, ${ }^{2}$ David Urban \\ ${ }^{1}$ The Children's Centre of South Bohemia, ops, Strakonice \\ ${ }^{2}$ University of South Bohemia in České Budejovice, \\ Faculty of Health and Social Studies, Department of Social Work
}

\begin{abstract}
In our field we increasingly meet families who fall into the endangered category. The notion of threat in the area of social and legal protections of children directly relates not only to specific individuals but also the family environment as a whole. For us it reveals the real situation in a family where one or more of its primary functions are suppressed. As a result of this, and under certain conditions, all the important, stable and stimulating environments are not ensured.

Social workers who deal with families who fall into the endangered category are more cautious in cases where children are present in the family. The main objective of the professional's work is to identify these families as soon as possible and offer them timely assistance through various support services. The sooner the family is identified and engaged, the less damage is done to the child.

Early and ongoing cooperation with the family offers an opportunity by which many problems can be solved. Redevelopment of the family is one of the ways how it can be achieved successfully. The Children's Centre in Strakonice has made a significant contribution to helping and supporting families for many years. The Participation Centre in collaboration with the family and other professionals unfortunately do not always show the results that we expect. The main role of the Children's Centre is to compile an
\end{abstract}


individual plan for family support and assistance based on family, social and medical history.

The importance of the Children's Centre role in affecting the active involvement of the family in the process of rehabilitation is discussed by Mgr. Martin Karas in his dissertation. Mgr. Martin Karas highlights one of several problems, namely the insufficient and unsystematic support for the family provided by assisting institutions. Insufficient assistance may be preventing a child from returning to his/her biological family. He pays close attention to the problems that prevent parents from devoting adequate attention.

The aim of the article is to show what the realities of active cooperation with families are. Also to show what primary findings we have reached after processing several interviews conducted with those who have successfully completed the remediation process.

Keywords: rehabilitation of families at risk, vulnerable children, multidisciplinary care with families, social work with families, individual care plans

\section{Introduction}

In our field we increasingly meet families who fall into the category of endangered ones. The notion of threat in the area of social and legal protection of children directly relates not only to specific individuals but also the family environment as a whole. For us it reveals the real situation in a family where one or more of its primary functions are suppressed. As a result of this, and under certain conditions, all the important, stable and stimulating environments are not ensured.

The family and environment should make children feel safe and secure, while interrelationships and connections must be balanced and adequate. The behaviour of parents should serve as a role model for the children since there is a great risk that this shown behaviour will be continued and applied by the children later in their life (Langmeier, J., Matějček, Z., 2011).

A certain degree of risk arises from insufficient and poor quality child care. Rather a lot depends on the ability of experts to be able to objectively assess the true risks and possibilities of children in danger (Dubowitz, H., DePanfilis, D., 2000).

It is generally known that a structured and properly stimulating family environment is the core of the successful development of all family members, especially that of the child. Such an environment has undoubtedly a very beneficial effect on the formation and strengthening of interpersonal relationships. 
The family significantly affects the development of children's personality and influences not only their social development, but primarily their physical and mental development. Children begin to form their understanding of the world, as well as the habits and patterns of behaviour as their family environment dictates. (Klégrová, Green, M., 2006).

Social workers, who in their work deal with families of the above categories, are much more prudent in those cases where a child is present in the family. Unhealthy family relationships, unstable environment, and improper and abusive behaviour may result in concealed risks for the youngest family members. These risks can include neglect, sexual harassment, and physical and psychological abuse.

Also the attitude, behaviour and the way parents deal with the neglected child is often unclear and unpredictable. The situation within the family and its operation is unstable. A parent who usually ignores the child causes friction between them and when this goes to extremes it often ends in violent scenes (Krejčíŕová, D. Langmeier, J., 1998).

In practice we increasingly see moments when children find themselves in an environment that directly threatens their life. The main task of social workers is to identify these families as soon as possible and offer them assistance through various support services. The sooner the family receives support, the less damage inflicts on the child.

Parents, who need help, do not want to see themselves as unsuccessful. The sense of parental failure shuts them away from the outside world, and thus the risk of problems arsing in the family are even greater. However, by educating such parents who see childcare as a fresh start due to the assistance of the support organisations, we can educate the whole of society. (Gjuričová, ড̌ ., Kubička, J., 2003).

Taking into account the need to ensure the immediate protection of a child's safety, in certain cases there is a need to urgently place the child in one of the different types of temporary care facilities which are offered in the Czech Republic. It may be an infant home, or children's home for up to three years (family type), or a facility for children requiring immediate assistance (children's centre).

In practice this measure primarily means the suppression of immediate threats in order to ensure the rights, protection, interest and welfare of a child who otherwise would need to grow up in a dysfunctional family. One way to help such families is the involvement of a multidisciplinary work team which deals with specific issues. In these cases emphasis is placed on providing support and assistance for the family in their natural environment. However, if it is not possible, whatever seems to be the reason, there is the opportunity to help and support them through the placement of children together with their mother at a 
children's centre. A residential service with social rehabilitation provides some protection, not only for the children but for the whole family. The advantage of this service is that it can prevent any delay in removing children from their own family, which became necessary because of threats within the family environment. These facilities also serve as training centres for mothers and families with children who need help in order to master skills associated with child care, with a special emphasis on strengthening the relationship between the parent (caregiver) and child.

Based on experience with vulnerable families, the primary consideration in childcare should be directed at giving careful attention to their individual needs and interests. In the context of fulfilling basic obligations, a timely and very close cooperation with the family needs to be established, with respect to the interest and welfare of the child. Systematic action can trigger an attitude change in parents, not only towards the child but towards themselves, too. (Bechyňová, 2008)

Early and ongoing cooperation with the family provides an opportunity to solve many problems. Redevelopment of the family is one of the ways it can be achieved successfully. It is a set of activities that allows you to prevent, reduce or eliminate the causes of becoming at-risk families (Bechyňová, V., 2008).

The Children's Centre in Strakonice has significantly contributed to help and support families for many years. Though, the Participation Centre, which collaborates with families and professionals, does not always show the results that are expected. We know from experience that any success a process is directly influenced by a range of internal and external factors, and exposed to both the family and the institutions. An absolutely crucial influencing factor in a successful process appears to be willingness, and if it is present, it will lead to establishing a lasting cooperation with families.

The primary role of the children's centre is to compile an individual plan for family support and assistance, based on family, social and medical history, which is decisive for all components of the multidisciplinary team.

Not only from the children's centre perspective, but also from other members of the multidisciplinary team it is necessary to establish close cooperation with the family as soon as possible. The active involvement of parents in the process of social rehabilitation is a must. While the Children's Centre as a facility providing protection for children also plays an extremely important role in this process. This role involves coordination between the family, the child and institutions.

The research undertaken within the framework of the doctoral thesis by Mgr. Martin Karas (supervisor doc. PhDr. David Urban, Ph.D.) aims at the importance of the children's centre affecting the active involvement of the family in the process of dealing with family problems, the analysis of partial 
implementation of individual plans of support with the identification of the components that are involved in the rehabilitation of family. We follow what ingredients are incorporated in the process of remediation, their extent and their interrelationships. Based on the documentation we provide a detailed family medical and social history, which is used to compare, understand and search for common features in each of the affected families. We observe how individual components affect the behaviour and rehabilitation of families. The key factor is the "moment" in which there is engagement of the parents in the process of remediation.

The aim of the article is to show what the reality of active cooperation with families is, moreover what primary findings we have reached by taking several interviews with those who had successfully completed the process of social rehabilitation. We aspire to know the answer to the following questions: What specifically leads parents to become actively involved? Why and when do these phenomena occur? Where does the key moment of their collaboration come from? It is accompanied by some significant connection identifiable in the verbatim transcripts of respondents' answers? We suppose that the obtained data will clearly show how the situation over certain periods of time and under certain situations is life changing for vulnerable families. Noticeable changes occur, for example, in situations that are essential for the family.

\section{Method}

One of the objectives of Mgr. Martin Karas research is to perform a sub-analysis of the implementation of individual plans for the rehabilitation of families, with identification of the components that are involved in helping and supporting families. Based on these findings, I identified the reasons why the family was included in the process of remediation.

With regard to the aforementioned reasons I follow which components participate or participated in a particular case. I follow relationships among family members, as well as mutual relationships within the family, with the redevelopment team and the Child Centre. In particular, how the individual components act and interact. I follow which parts of the multidisciplinary team supported the family, the length of this support and their direct influence on the behaviour and actions of parents in connection with a successful restructuring process.

The key task of the dissertation is to capture the moment of the phase of social rehabilitation when the family becomes engaged. After close observation we can conclude the moment when the parent's active involvement in 
cooperation can be recognized - supposed they come spontaneously at least three times during the six-week visit from the competent child protection authority, and with the specific goal to gain further support and assistance. The obtained data also compares families which had completed the social rehabilitation successfully. These families seek out compromises that lead to successful goals.

Objective results could also be applied to other at-risk families. When these findings can be followed, families can be sorted into predefined categories based on the actual process of social rehabilitation. Suggestions and possible corrections to individual plans of support and care can be made so that the whole process will significantly accelerate.

In the framework of this thesis a qualitative form of data collection was used with secondary data analysis. For data collection I began with the available medical documentation (from health institutions), social documentation (provided by the child protection), psychological documentation (psychological reports and assessments) and other documentation as well, which were managed and archived in the Children's Centre South Bohemian Region, O.p.s. Strakonice. Other sources of data are in-depth interviews with families which are still active or were active.

The target set for the research are families whose children have been placed in the Children's Centre since 2006 (the Children's Centre of South Bohemia, ops in Strakonice was founded in this year) but after a successful social rehabilitation have returned to the custody of their parents. There are about 30 families whose files have been submitted to this analysis (it is about a fifth of the clientele over the life span of the Children's Centre).

\section{The Children's Centre}

The Children's Centre was founded to be operated similarly to nursing homes and homes for children up to 3 years. A part of the children's centre is a boarding unit for children and for parents with children, an infant home (resp. Children's home), a family-type facility for children needing immediate assistance from a daily facility, accommodation for mothers (parents), and a training room for mothers right before delivery. The family team's specialist also provides family counselling and we prepare applicants for NDP, meet with families (foster parents, adoptive parents) and others (Schneiberg, F., 2009).

The primary role of the Children's Centre is to assemble individual plans of support and assistance based on family and social history, which is decisive for the other members of the rehabilitation team and for the entire process of social rehabilitation. The basic structure of the team is: parents, staff of the children's 
centres, OSPOD, a paediatrician and a child psychologist. This may be supplemented with other necessary experts according to the individual needs of the family. Remediation means continuous multidisciplinary collaboration of the institutions involved which systematically collaborate with the family, and favourably affects their social conditions and attitudes. In terms of the children's centres, when redevelopment is completed successfully, the child is released into the care of parent(s) (Bechyňová, V., 2008).

The skills related to child care are a set of specific activities aimed to achieve independence and self-sufficiency and to develop their specific capabilities. At the same time they strengthen and train the necessary skills for life (Act no. 108/2006 Coll., On social services).

\begin{tabular}{|l|l|}
\hline Year & Residential services within Social Rehabilitation \\
\hline $\mathbf{2 0 0 8}$ & 7 adults +7 minors \\
\hline $\mathbf{2 0 0 9}$ & 7 adults and one minor mother +5 minor \\
\hline $\mathbf{2 0 1 0}$ & 12 adults +5 minors \\
\hline $\mathbf{2 0 1 1}$ & 22 adults +7 minors \\
\hline $\mathbf{2 0 1 2}$ & 19 adults +2 minors \\
\hline $\mathbf{2 0 1 3}$ & 28 adults +1 minors child \\
\hline $\mathbf{2 0 1 4}$ & 47 adults +11 minors \\
\hline
\end{tabular}

Table 1. Total number of clients placed, in the context of social rehabilitation, in the period from 2008 to 2014 .

Table 1 illustrates the total number of clients who participated in residential social rehabilitation services for family redevelopment. Family redevelopment in the childhood centre may occur for various reasons, but it also provides outpatient help and support. These clients are not included in the statistics.

Eight interviews were taken with participants who have successfully completed social rehabilitation. The main causes of their participation were:
a.) substance abuse
b.) substance abuse-related crime
c.) child neglect
d.) domestic violence 
A few years ago the main reason for admission was primarily child neglect. It was often associated with poor economic and housing situations of the family and parents often consumed alcohol. Currently, there is a widespread drug abuse, especially smoking marijuana, but also methamphetamine in various forms. "Once I tried meth, but it did nothing to me. Sometimes I smoke marijuana, but that's more because of partying. I was addicted to sniffing toluene. I got through a small can a day. But it was really horrible, I felt sick. Maybe even for three days, I felt out of breath that is no acetone. "(Source: own research).

The main reasons for the admission of clients in social rehabilitation often include:

a.) the state of health of the child or the parents

b.) the age of the parents

c.) the poor economic situation of the family

d.) substandard housing conditions

e.) and poor family relationships

The health condition of the child or parents is often crucial in the process of social rehabilitation. Long-term poor or deteriorating health and mental condition of the child is a signal that the parent cannot cope with their situation. This fact is due to the deteriorating health and mental state of the parents. These two aspects go hand in hand and interact with each other: "I'm not managing myself, I wasn't mentally ready, and I had to take pills. I just could not handle a little baby." (Source: own research)

Age plays an important role in the quality, capability and ability of parents to be able to provide parental care. In the fact it is very noticeable what a teenage mother said "I wanted to have a child, but I did not know it would be so demanding, as I simply do not have time to go out with the girls which is sometimes needed in the evenings". (Source: own research)

This fact is even more enhanced, if the mother is too young and grew up in an institution like an orphanage: "I did not realize I would have to do so many things. Like the laundry or wash the dishes, I'm like really tired. I did not have to do it at home. Cook, something I can't do, I wasn't taught. Maybe make tea or buttered bread. Otherwise, I simply buy things." (Source: own research)

Satisfactory family ties and relationships are extremely important for life however, in these families they tend to be significantly disrupted. Poor quality family connections, associated with aggression and violence are unacceptable for an average partner: "Friend, this is what my girlfriend's father did, we were arguing and he beat me several times. We fought because they did not like to 
work, and we had no money. Then I slapped him in front of his daughter, so I ran. " (Source: own research)

Admission to social rehabilitation was made by the participants:

a.) voluntarily

b.) on the recommendation of OSPOD (department of social and legal protection of children)

c.) on the recommendation of family

Possessing the voluntary agreement of clients by the children's centre is always an advantage. There is a strong likelihood that they will spontaneously and actively engage in activities that will address their difficult situation. However, the truth is that the clients are mostly in their natural environment when in long term cooperation with OSPOD. Provided there is no desire to change this, they are systematically guided and motivated to tackle their situation through the available accompanying services. For unknown reasons, however, they deny this fact: "I joined myself. Mom told me she contacted the centre and was told, they will help me there and that she could lose a son. And so I joined. " (Source: own research)

In this case, the social worker said: "I worked with the client for a few months. We agreed on certain steps that should be undertaken, but after all this time, nothing happened. Additionally he still used drugs. I told her that if he does not enter social rehabilitation and proves he is really able to deal with his situation, he may lose a son. " (Source: own research)

Based on my own experience it is necessary to mention the fact that the participants mainly follow the recommendations of the family rather than the recommendation of OSPOD. Due to family traditions or patterns it is difficult for the family to admit that their child has a problem. They fear of the loss of confidence, that their children will condemn them and break all ties and relations. It is a compelling argument therefore they constantly say: "I do not know why you think that! My daughter has no problems! And if she has, we have always helped her. I think that is what would help her now. I think it just does not work! But when you want, so you say go there. " (Source: own research).

Active participation in the process of social rehabilitation:

a.) from the beginning of the stay

b.) during the stay (gaining confidence)

c.) after repeated admission (after completion of repeated stays at abuse facilities) 
Spontaneous cooperation from the beginning of the stay is evident for clients who actually volunteered to stay. Positive outcomes and the length of stay are clearly influenced by this fact. Spontaneous cooperation that began during the stay commences after a certain time. Active collaboration with clients occurs after an adaptation time, since when the participant commences the use of services provided and trust in the workers. The length of this period differs. If mutual trust or communication does not occur, social rehabilitation does not make sense: "When my social worker told me she started, so I joined. I did not know what to expect. When you told me that you will help me, so I thought it was pretty much bullshit. Before I ran, I realized that you treat me nicely, and that I really want to help myself. And then it all went quiet, I mean, sometimes well, sometimes alone as bad as ever. " (Source: own research)

If the rules of the children's centre are repeatedly and grossly violated the participants must immediately leave the facility. There is a considerable risk in removing the child from the mother's care. The mother soon realizes this fact. "I realized that I had to act and start doing something when I had to leave that week. That was for me the very greatest hell. I realized this especially when you threw me out after ten days." (Source: own research)

Important aspects of the process of social rehabilitation:

a.) Trust the plan

b.) Motivation

c.) Good communication and empathy

d.) Respect for the individual needs

In the process of social rehabilitation, mutual trust between those who identify themselves as employees of the centre and the participant is important in order to enable a successful and fruitful cooperation. It is also equally important to perform good communication and feel empathy. For example, one of the participants stated: "I say they just got to believe, that they do not cross me. I've always been in my life someone who has been tripped. First they promise things and it does not happen, and then I will get baked. They had done this in the city, and with them, I would never want to have anything." (Source: own research)

Another client said: "I just know that they understand me and know what I need. They called me several times when I was still at home, it happened just like that, they call, yeah we want to help you, we do understand your problem, and that I can do it for myself, that I wasn't terrible. So that is it that yeah!'”(Source: own research).

A social worker said: "Mutual trust on both sides is very important in the whole process of rehabilitation, as well as good communication, although it is 
sometimes not easy. Clients need to know that we understand them and that we care about them, that we understand their problems. It's a question of empathy." (Source: own research)

No social service can work without motivation. Stimulating clients is a challenging task without which, however, the work does not move forward. Once we can get the client engaged, we have made a gain. What is even more difficult is to sustain this state. It is a task that falls onto the shoulders of the social worker. It depends on their skills and natural intuition to know when you need to make a change: "The motivation of the client is sometimes very difficult. Above all, he really knows what he wants. Clients have short attention spans, so you have to constantly change activities to capture them. There are clients who generally do not want to do anything. They're not used to fulfilling obligations, because they never had to do it. They are low profile. In my neighbourhood I have clients with whom I cannot do anything because they are not willing to do anything." (Source: own research)

Sense of social rehabilitation from the perspective of participants:

a.) is important

b.) has meaning only in some areas

c.) has no meaning

Social rehabilitation is greatly relevant for participants who have successfully mastered the entire process by themselves. This is important in certain areas of the country where support is not available. These are life situations which are not the competence of the children's centre. For example - correct mutual family ties, finding a new relationship, providing improved housing or financial situation. These are skills that are fully the responsibility of the client. Children's Centre in these areas can provide only one option: consultancy: "Yeah, the stay with you was almost meaningless. I thought you would handle everything, I thought you'd get me an apartment and a job. With that, I've always had a problem, and none of you gave me a job. How am I supposed to buy an apartment then? From the benefits it is difficult to pay." (Source: own research)

Another participant said: "I'm really glad that I was here. Can I also contact you if I need to, if I have a problem? This to me is such a certainty. I think I've changed." (Source: own research) 


\section{Conclusion}

Successful assistance and support for families at risk are affected by many factors, by the families, the facilities providing social and legal protection of children, the child protection authority, as well as other institutions involved. I believe that on the basis of personal experience, it is necessary to monitor the attitudes, ideas, opinions, prejudices and interests that prevent all stakeholders from paying attention to real problems.

Reliable verification of these assumptions is the subject of my dissertation research. We consider it desirable to purposefully, intentionally and systematically build a unified system of care for vulnerable families with a range of sufficient supporting services. Based on these findings, we will be able to identify the causes and the ways how the existing multidisciplinary assistance can help and what prevents the return of children to their biological family.

However, conducted research shows that with mutual cooperation, trust, communication, empathy and stimulation the process of social rehabilitation "under certain conditions" moves forward. Certain conditions are primarily meant: the client will cooperate and participate actively in all activities, systematic and effective children's centres, social workers and other stakeholders.

Currently we regard about the half of clientele as successful. This is probably due to a greater promotion and the use of newly formed social services that try to help families by paying attention to the child's interest in order to be able to help themselves. Multidisciplinary team work is more systematic with a focus on individual clients' needs.

The results from the questionnaires show that in working with the family there is some positive movement. Therefore, it is relevant for us to verify all the facts, it is necessary to carry out further detailed investigations and collect new sample participants.

\section{References}

1. BECHYŇOVÁ, V., KONVIČKOVÁ M. 2011. Sanace rodiny. Praha: Portál, 2011. 152 s. ISBN 978-80-262-0031-4.

2. DUBOWITZ, H., DEPANFILIS, D. 2000. Handbook for Child Protection Praktice. Sage Publication, Inc. Thousand Oaks, 2000. 683 s. ISBN 0-76191370-8.

3. GJURIČOVÁ, Š., KUBIČKA, J., Rodinná terapie systemické a narativní prístupy. Praha: Grada, 2003. 177 s. ISBN 80-247-0415-3 
4. KLÉGrovÁ, A., ZELENÁ, M., Podpora rodiny. Praha: Vzdělávací institut ochrany dětí, 2006. 32 s. ISBN 80-86991-67-9.

5. LANGMEIER, J., KREJČÍŘOVÁ, D., Vývojová psychologie. Praha: Grada, 2006. 368 s. ISBN 978-80-247-1284-0.

6. MATĚJČEK, Z., LANGMAIER, J., Psychická deprivace v dětství. Praha: Karolinum, 2011. 400 s. ISBN 978-80-246-1983-5.

7. VĚSTNÍK, Činnost kojeneckých ústavů a dětských domovi̊ pro děti do 3 let, Praha: Ministerstvo zdravotnictví ČR, částka 9, metodické opatření č. 7, Zn. 24039/2009, 2005.

8. Zákon č. 108/2006 Sb.o sociálních službách. [online]. [cit. 2007-01-01]. Dostupné z: <http://atre.cz/zakony/page0048.hmt

\section{Mgr. Martin Karas}

The Children's Centre of South Bohemia, o.p.s.

Radomyšlská 336

38629 Strakonice

e-mail: martin.karas.strakonice@seznam.cz

and

University of South Bohemia in České Budejovice

Faculty of Health and Social Studies

Department of Social Work

doc. PhDr. David Urban, Ph.D.

University of South Bohemia in České Budejovice

Faculty of Health and Social Studies

Department of Social Work

e-mail: durban@zsf.jcu.cz 
